\title{
Sports in Indonesian Islamic Community Culture
}

\author{
$1^{\text {st }}$ D Sofyan \\ Universitas Majalengka \\ Jl. Raya K H Abdul Halim No.103, \\ Majalengka Kulon, Kec. Majalengka, \\ Kabupaten Majalengka, Jawa Barat \\ 45418 Indonesia \\ davisofyan@unma.ac.id \\ $4^{\text {th }} \mathrm{N}$ Kusmaedi \\ Universitas Pendidikan Indonesia \\ J1. Dr. Setiabudi No.229, Isola, \\ Kec. Sukasari, Kota Bandung, Jawa \\ Barat 40154, Indonesia
}

\author{
$2^{\text {nd }} \mathrm{Y}$ M Saputra \\ Universitas Pendidikan Indonesia \\ Jl. Dr. Setiabudi No.229, Isola, \\ Kec. Sukasari, Kota Bandung, Jawa \\ Barat 40154, Indonesia
}

\author{
$3^{\text {rd }}$ A J Nurihsan \\ Universitas Pendidikan Indonesia \\ J1. Dr. Setiabudi No.229, Isola, \\ Kec. Sukasari, Kota Bandung, Jawa \\ Barat 40154, Indonesia
}

\begin{abstract}
History records that sport has become an important part of Muslim civilization, but it is covered by the notion that the development of sports only originates from the civilization of the Western world. The danger that may arise from this assumption is that it creates superiority in the character and culture of European nations, simultaneously causing inferiority to the character of other nations, especially Muslims. Sports in Islam is synonymous with training the body, mind and spirit. Indonesia as a country with the largest number of Muslims in the world, of course, Islamic culture is thick in everyday life, including in the activity of sports. The purpose of this article is to explore the culture of the Islamic community in Indonesia in relation to sports. This article uses a qualitative descriptive method to support the achievement of the objectives of this article.
\end{abstract}

Keywords-Sports, Indonesia Islamic, Community, Culture

\section{INTRODUCTION}

Everything that is obtained by humans in the form of physical or non-physical nature is the result of systematic or unsystematic motion that is controlled by the heart and is responded by his mind and interpreted by his movements. In Islam, the body is considered a gift from God, and therefore it is important to care for it [1]. In Islam, it is permissible to participate in sports following the sunnah of the

Prophet Muhammad SAW (following Islamic law). Participation in sports is not against the spirit of Islam and "sharia" (Islamic life code) [2]. Religion should not be separated from sports activities and religion is directly involved in it. The position of sports activities is a reflection of gratitude towards the creator who has bestowed the body with a very perfect composition. In addition, of course, will have an extraordinary impact on the morality of the individuals involved.

\section{RESEARCH METHODS}

Research is a systematic process by which we know more about something than we did before engaging in the process (Merriam, 2009). This article aims to see an overview of the Indonesian Islamic community in particular regarding sports. This article uses a descriptive analysis method to support the achievement of the objectives of this article. In this article, data sources are collected from articles, newspapers and other sources related to the culture of Indonesian Islamic society. The analysis used involves the process of investigating, recording, processing, and interpreting primary historical data or sources.

\section{RESULT AND DISCUSSION}

\section{A. Sports in Islamic Perspective}

Islam has made a lot of efforts to maintain health and develop healthy lifestyles, it has been necessary for and encourages involvement in physical culture and sports with the aim of improving health, protecting oneself and family, and motherland [3]. Islam considers health number one as important only for faith and argues that an individual, society and the state share responsibility for health promotion [4]. The direct references to horse riding, shooting, swimming, hunting, fencing, running, and wrestling found in the Koran and Hadith reflect the concern of Muslims training for a military that is healthy and ready in case of war [5]. Muslims certainly do not reject sports as long as they are not excessive and only lead to worldly fame.

Referring to the Koran and various hadiths, that women in sports are not prohibited, states that Islam views physical activity and sports positively for reasons of health and recreation [6]. The consensus in much of the literature is that Islam is an ideology that urges its followers to take up 
recreational, physical, and / or competitive activities. The use of religious texts such as Qur'anic verses (sura) and written notes of the Prophet Muhammad's teachings (Hadith) has been frequently used by some Muslims to describe Islamic positive views on sport [7]. The health argument is often presented as the main reason for encouraging Muslims to exercise.

Islam has recommended that we take care of our bodies and do some sports and do it only for Allah SWT, for the Hereafter, for the Qur'an and for the Prophet Muhammad. Everyone believes in Muhammad SAW is a human being who is enthusiastic, a healthy and strong body and is able to carry out the movement and vitality of his life [8]. Prophet Muhammad argued, 'it must be the one who takes care of the mind and body [9]. This is reinforced by the statement which states that: "The desire to maintain physical health and the call for a 'healthy soul in a healthy body' are part of Muslim heritage [10].

\section{B. Overview of Indonesian Sports}

Sport is an important part of Indonesia's national culture [11]. Soekarna, the country's first president, described Pancasila as five principles, namely nationalism, humanity, democracy, social justice and monotheism. Soekarno began to install mechanisms for developing national unity and integration by forming a large part of the Dutch East Indies Youth through local sports clubs. These clubs became opponents of Dutch rule during the colonial period. In some respects the independence and nationalistic spirit of Indonesian youth is brought to life through sports [12].

The creator of the national anthem of Indonesia Raya, WR Supratman, also seems to realize the importance of sport. This is stated in the lyrics of the song Indonesia Raya, one of which reads "... Wake up the soul, wake up the body, for Indonesia Raya ..." [13]. The song's lyrics illustrate that in order to become a country that is strong and has character, every citizen must build his body and soul strength. Of course, mental strength is built through religious teachings, while physical strength is built through sports activities. So that there will be a balance of individuals in carrying out activities in the form of individual struggles in survival or fighting for the interests of the nation and state.

Soekarno considered the 1962 Asian Games award which was held in Indonesia as an opportunity to demonstrate freedom from European influence [12]. Soekarno through a spokesman stated that sports cannot be separated from politics which then formed a new organization with specific objectives of advocacy for the interests of third world sports and other non-aligned countries. The organization is called the Games of the Newly Emerging Forces (GANEFO) with one of its goals being to run a multi-sport game every two years [12].

As has been further analyzed by the holding of the Asian Games in Indonesia for political messages and the deliberate mixing of sport and politics sparked a longer strife between Indonesia and the IOC [14]. Indonesia refused to grant visas to participants and officials from Taiwan and Israel as relations with friendly foreign relations with the Republic of China and Arab countries [15].

Sport is considered an important part of the development of the Indonesian nation, as, for example, Soekarno's comments to the athletes on April 9, 1961 in Bandung were shown, "The fifth side of our revolution, namely sports, is very important and that is what we want. become a new Indonesian human being who can face the world with eyes open, upright, with a strong body, mental and spiritual strength " [14]. In many ways, Indonesia can be judged as a classic example of the use of sports in developing countries. Sport has been used for nation building, integration of different cultures, improvement of health, strengthening of cultural identity and gaining international recognition. Political leaders have taken advantage of opportunities to be associated with sports [12].

The actual condition of Indonesian sports in accordance with the mandate of Law No. 3 of 2005 concerning the National Sports System outlines that Indonesian sports policies must be based on joint initiatives and joint encouragement between the government and the community in the sense that the roles of both must be balanced. Another poll, conducted by the Jakarta-based Center for Strategic and International Studies (CSIS) with 600 millennial respondents (ages 17 to 30 ) and 851 nonmillennial respondents (over 30) in 34 provinces from 23 to 30 August 2017 revealed that millennials prefer to exercise $(30.8 \%)$ [16]. This explains that sport has become a big magnet for the culture of Indonesian society.

\section{Interpreting Sports in the Culture of Islamic Society in Indonesia}

Culture shapes values, attitudes and beliefs, which determine behavior and life choices. Learning about the culture in which we live is a means of understanding the world. Culture shapes values, attitudes and beliefs, which determine behavior and life choices [17].

Sport is culturally determined by what man thinks of his body, how he thinks about himself in relation to his body, how he thinks his body should be trained, disciplined, developed, educated [18]. Sport is formed by and derives symbolic meaning from its close relationship with society [19]. Sports culture is a strong predictor of sport participation and life aspirations (both intrinsic and extrinsic pursuit of goals) [20]. One of the many objects of desire that has won the hearts, minds and souls of many peoples is sport. Sport has a central place in the fabric of life for many cultures around the world [21].

Sport is an integral part of culture developed by humans, in culture there are 8 institutions (institutions), each of which consists of various activities, material culture and the underlying ideas. The eight institutions are: domestic, economic, religious, educational, scientific, political, aesthetic and recreational institutions, as well as somatic institutions [22]. Sports can be categorized into two institutions, namely aesthetic and recreational institutions and somatic institutions relating to healthy living by maintaining and maintaining physical fitness.

Soekarno's statement regarding the main motive for Indonesians to be involved in sports was, "I hope that you are involved in sports not only for your personal benefit, to 
become a tennis champion, to be a champion of badminton, to be a champion of football ... but for Indonesia's prestige and 'dedication of life. 'to Indonesia " [23]. From this statement, it is implied that building a nation, building a nation's identity can be through sports. Despite the tremendous technological improvements in many areas of life, humans remain an actor in the process of civilization and sport [24].

Sports to shape community and to generate conflict, for individual pride or ethnic pride, for nationalism or for international conquest embody material culture [25]. All the elements of success, trophies and fans, combine to create a level of culture that is a very visible and valuable part [26]. Talking about sports, watching sporting events, and playing sports forms a kind of cultural currency in society, where those who can do these things well achieve admiration and respect [27]. Mandela said "sport has the power to change the world. It has the power to inspire. It has the power to unite people in a way that no one else does [28]. For Indonesian people in general, sport is not yet a good opportunity to guarantee life.

In a live interview with Eric Kruk, a founder of Fighting Arts of West Sumatra in Virginia, United States on March 30, 2019 at 14.00 WIB, located in Sabda Alam, Garut, West Java, revealed that, "... silat sport is synonymous with Islam, Indonesian culture. By learning silat the students become better and have a visionary view of life and the most expensive thing in learning silat is a change for the better ". Many areas in Sumatra are one of the major islands in Indonesia, Muslim terms and phrases such as saying "Bismillahi al-rahman al-rahim" (In the name of Allah, Most Gracious, Most Merciful) and references to Muslim spirits are added to prayer, cosmology and pedagogy martial arts [29].

Pencak Silat is part of the culture of Indonesian society that has developed since time immemorial. In particular, the pillars of building national identity and character. Various sports faculties in which teach pencaksilat kulaih, pencaksilat sports colleges, and pencaksilat extra-curricular in schools and rural areas in the archipelago continue to be developed to give birth to the fifth pillar of cultural development, namely the development of adequate and professional Human Resources in their fields [30]. Indonesia occupies a strange place in global soccer culture. Football is everywhere in Indonesia such as on the streets, in narrow alleys, in large and overcrowded stadiums, and in many slum areas. In most contemporary cultures, ideas, images and ideologies of national identity are very often carried out through sporting events [31].

\section{CONCLUSION}

Sport in Indonesian society certainly has its own historical value, especially for individuals who are Muslim. Pencak silat as Indonesia's cultural heritage has made the sport a national identity which is thick with the scent of Islam. Finally, I hope that in the future there will be more concrete studies to study sports from various scientific fields, especially those related to religion and culture.

\section{REFERENCES}

[1] K. Walseth, "Sport within Muslim organizations in Norway: Ethnic segregated activities as arena for integration," Leis.
Stud., vol. 35, no. 1, pp. 78-99, 2016.

[2] M. K. Marwat, S. Zia-ul-Islam, M. Waseem, and H. Khattak, "Islamic perspectives with reference to health and participation in sports," Asian J. Soc. Sci. Humanit. Vol, vol. 3, no. 3, 2014.

[3] I. A. Galimov, "The Attitude Of The Religion Islam To The Physical Culture, Sport And Healthy Lifestyle," Int. J. Humanit. Cult. Stud. (IJHCS) ISSN 2356-5926, vol. 3, no. 2, 2016.

[4] D. Kahan, "Adult physical inactivity prevalence in the Muslim world: Analysis of 38 countries," Prev. Med. reports, vol. 2, pp. $71-75,2015$.

[5] D. Kahan, "Islam and physical activity: Implications for American sport and physical educators," J. Phys. Educ. Recreat. Danc., vol. 74, no. 3, pp. 48-54, 2003.

[6] K. Walseth and K. Fasting, "Islam's view on physical activity and sport: Egyptian women interpreting Islam," Int. Rev. Sociol. Sport, vol. 38, no. 1, pp. 45-60, 2003.

[7] S. Farooq and A. Parker, "Sport, physical education, and Islam: Muslim independent schooling and the social construction of masculinities," Sociol. Sport J., vol. 26, no. 2, pp. 277-295, 2009.

[8] O. Kizar, "The place of sports in the light of quran, hadiths and the opinions of the muslim scholar in islam," Univers. J. Educ. Res., vol. 6, no. 11, pp. 2663-2668, 2018, doi: 10.13189/ujer.2018.061132.

[9] H. S. Ndee, "Islam and Islamic culture: Earliest foreign influences on physical activity in pre-colonial East Africa," Int. J. Hist. Sport, vol. 27, no. 5, pp. 798-819, 2010, doi: 10.1080/09523361003625857

[10] U. Shavit and O. Winter, "Sports in contemporary Islamic law," Islam. Law Soc., vol. 18, no. 2, pp. 250-280, 2011, doi: 10.1163/156851910X537784.

[11] S. Moser, "Creating citizens through play: The role of leisure in Indonesian nation-building," Soc. Cult. Geogr., vol. 11, no. 1, pp. 53-73, 2010, doi: 10.1080/14649360903414577.

[12] I. Adams, "Pancasila: Sport and the building of Indonesia Ambitions and obstacles," Int. J. Hist. Sport, vol. 19, no. 2-3, pp. 295-318, 2002, doi: 10.1080/714001759.

[13] M. Hasan, "Olahraga perspektif hadis," UIN Sunan Kali Jaga Yogyakarta, p. 48, 2013

[14] S. Hbner, "The fourth Asian games (Jakarta 1962) in a transnational perspective: Japanese and Indian reactions to indonesia's political instrumentalisation of the games," Int. J. Hist. Sport, vol. 29, no. 9, pp. 1295-1310, 2012, doi: $10.1080 / 09523367.2012 .677035$

[15] F. Trotier, "The legacy of the games of the new emerging forces and Indonesia's relationship with the international Olympic Committee," Int. J. Hist. Sport, vol. 33, no. 12, pp. 1321-1340, 2017, doi: 10.1080/09523367.2017.1281801.

[16] B. Irawanto, "Young and Faithless: Wooing Millennials in Indonesia ' s 2019 Presidential Election," ISEAS Yusof Ishak Inst., no. 1, pp. 1-10, 2019.

[17] T. Benn, S. Dagkas, and H. Jawad, "Embodied faith: Islam, religious freedom and educational practices in physical education," Sport. Educ. Soc., vol. 16, no. 1, pp. 17-34, 2011, doi: $10.1080 / 13573322.2011 .531959$.

[18] R. Cassidy, "The Cultural Definition of Physical Education," Quest, vol. 4, no. 1, pp. 11-15, 1965, doi: 10.1080/00336297.1965.10519577.

[19] O. Weiss, "Identity Reinforcement in Sport," Int. Rev. Sociol. Sport, vol. 36, no. 4, pp. 393-405, 2001.

[20] C. K. J. Wang, W. C. Liu, H. Nogawa, and Y. Sun, "The influence of japanese sporting culture and motivation on sport participation and life aspirations," Asia Pacific J. Sport Soc. Sci., vol. 4, no. 2, pp. 113-123, 2015, doi: 10.1080/21640599.2015.1065567.

[21] B. S. Wall, "The Culture of Sport, Bodies of Desire, and the Body of Christ," J. Disabil. Relig., vol. 21, no. 2, pp. 142-151, 2017, doi: 10.1080/23312521.2017.1287617.

[22] Museumku, "Memaknai Olahraga dalam Kebudayaan," 2014

[23] R. Lutan, "Indonesia and the Asian Games: Sport, nationalism and the "new order," Sport Soc., vol. 8, no. 3, pp. 414-424, 2005, doi: 10.1080/17430430500249175.

[24] M. Krüger, "Global perspectives on sports and movement cultures: From past to present - Modern sports between nationalism, internationalism, and cultural imperialism," Int. J. 
Hist. Sport, vol. 32, no. 4, pp. 518-534, 2015, doi: 10.1080/09523367.2015.1017473

[25] L. J. Borish and M. G. Phillips, "Sport history as modes of expression: Material culture and cultural spaces in sport and history," Rethink. Hist., vol. 16, no. 4, pp. 465-477, 2012, doi: 10.1080/13642529.2012.728382.

[26] P. J. Schroeder and J. P. Scribner, "'To honor and glorify God": The role of religion in one intercollegiate athletics culture," Sport. Educ. Soc., vol. 11, no. 1, pp. 39-54, 2006, doi: $10.1080 / 13573320500453420$.

[27] A. Blazer, "Religion and Sports in America," Relig. Compass, vol. 6, no. 5, pp. 287-297, 2012, doi: 10.1111/j.17498171.2012.00347.x.
[28] S. Keshkar et al., "The role of culture in sports sponsorship: An update," Ann. Appl. Sport Sci., vol. 7, no. 1, pp. 57-81, 2019, doi: 10.29252/aassjournal.7.1.57.

[29] M. Kartomi, "Traditional and modern forms of pencak silat in Indonesia: The suku mamak in Riau," Musicol. Aust., vol. 33, no. 1, pp. 47-68, 2011, doi: 10.1080/08145857.2011.580716.

[30] M. M. Purbojati, "Penguatan Olahraga Pencak Silat Sebagai Warisan Budaya Nusantara," J. Budaya Nusant., vol. 1, no. 2, pp. 141-147, 2014.

[31] T. Tanasaldy and C. Palmer, "Discrimination, sport and nation building among Indonesian Chinese in the 1950s," Indones. Malay World, vol. 47, no. 137, pp. 47-65, 2019, doi: 10.1080/13639811.2019.1559564. 